\title{
Understanding and Utilizing Adjunct Professors for Non- traditional Engineering and Technology Graduate Education
}

\author{
D. D. Dunlap, ${ }^{1}$ R. E. Willis ${ }^{2}$ D. A. Keating, ${ }^{3}$ T. G. Stanford, ${ }^{3}$ \\ R. J. Bennett, ${ }^{2}$ M. I. Mendelson, ${ }^{4}$ M. J. Aherne ${ }^{5}$ \\ Western Carolina University ${ }^{1} /$ St Thomas University ${ }^{2 /}$ \\ University of South Carolina ${ }^{3} /$ Loyola Marymount University ${ }^{4 /}$ \\ University of Alberta ${ }^{5}$
}

\begin{abstract}
Re-envisioning adjunct faculty members for non-traditional engineering graduate education is developing ways to effect a national dialogue on how to re-envision and position engineering graduate education to meet both the technology and societal needs of the 21st century. This paper adds value for the preparation of adjunct faculty members as graduate instructors and future teaching scholars. The paper contains an expanding set of Promising Practices in engineering and technology education that are currently being used. Teaching at the graduate level requires a high level of motivation in faculty who are committed to excellence in knowledge, in research, and in contributions to the profession, and/or serve to the community. Adjunct professors are an excellent way to bridge with the community and add richness to many course and degree program offerings.
\end{abstract}

\section{Historical Perspective}

The role of the adjunct within the modern university professional school is ambiguous something more than a casual visitor - less than a fully participating member of the faculty. This changing role of the adjunct is closely related to the changing role of the professional school itself. To consider the potential role of the adjunct it is necessary to understand this common evolution.

During the seventeenth and early eighteenth centuries, the college or university focu sed on the humanities and the classical languages of Greek and Latin. Gradually this curriculum expanded to include the natural sciences. By the end of the eighteenth century the forerunners of the social sciences such as political economy and sociology were becoming accepted. Practical skills and professions were still learned primarily through apprenticeship.

The "learned professions" of theology, medicine, and law increasingly drew their members from those with prior university training and were gradually (and often 
grudgingly) accepted within the university structure. Engineering and business (now management) were still learned through apprenticeship supplemented by courses - often evening courses - taken at mechanics' institutes and "colleges" of business. " By the beginning of the nineteenth century however, the increasing complexity of technology, markets, and organizations required greater preparation than could be obtained through this informal system. "Shop culture" was being replaced by "school culture., 3

One of the first of the new professional schools was the Rensselaer School (now Rensselaer Polytechnic Institute) established at Troy, New York in 1824. ${ }^{4}$ From the beginning, emphasis was on practical experience including field and laboratory work (referred to in the curriculum as "scholastic amusements"). 5 Close relations were maintained with graduates and other practicing engineers. For example, graduates were expected to communicate at least once in three years the results of their investigations and discoveries. ${ }^{6}$

By 1827, RPI began to stress the graduate status of the school - courses at the institute were intended primarily for those who had completed their academic education and special provisions were established for graduates of recognized colleges and the US Military Academy. ${ }^{7}$

As the population of the United States moved westward more and more state universities were established: Ohio in 1804, Michigan in 1817, Indiana in 1820, Wisconsin in 1848. In many cases there was conflict between those who wanted to pattern these schools on the east coast liberal arts models such as Harvard and those who wanted them to focus on practical training. In the latter case this was satisfied by including schools of "practical arts" or courses in mechanics, accounting, and agriculture. Graduates of RPI often played important roles in developing these. ${ }^{8}$ This approach expanded rapidly after the passage of the Morrill Land Grant Act in $1862 .^{9}$

Early engineering schools maintained close working relationships with both their graduates and with other practicing engineers and managers. Professors held simultaneous or intermittent positions in government and industry. Through both choice and necessity, the new schools drew on outside groups for faculty. Practicing engineers and managers also played important roles in the development of the professions of engineering and management and in the development of professional societies - Civil Engineers in 1852, Mining Engineers in 1871, Mechanical Engineers in $1880 .{ }^{10}$ To cite a few examples: Henry R. Towne, President of the Yale \& Towne Manufacturing Company, whose 1886 paper at the ASME meetings, "The Engineer as an Economist," led to the formation of a section within the ASME on engineering economics and the field of industrial engineering, Frederick W. Taylor whose application of engineering principles to shop management led to the development of "Scientific Management," an approach that dominated management thought for well over 50 years, Edward A. Filene, President of William Filene Sons department store (and Filene's Basement), and Henry S. Dennison, President of Dennison Manufacturing Company. All of these men were active in professional societies both in the United States and internationally. They worked professionally, wrote and presented papers, and played active roles in the development of

"Proceedings of the 2002 American Society for Engineering Education Annual Conference \& Exposition Copyright (C) 2002, American Society for Engineering Education" 
manufacturing and management thought. In 1931, McGraw-Hill published the text, Organizational Engineering, by Henry Dennison. ${ }^{11}$ These men and many others like them regularly lectured at universities throughout the United States and the world.

Thus, throughout the first half of the twentieth century there was an active interchange between the professional schools and the practicing professions. At the same time, the definition of a professional school expanded to include fields such as education, social work, communications, and mortuary science. But by the 1950 s this interchange had begun to wane. Following World War II, the GI Bill attracted thousands of veterans into the universities. Anxious to make up for lost time they crowded into the professional schools. The increasing visibility of these schools again raised the concerns over the role of professional schools within the universities.

This concern was expressed in different ways. The most relevant here was that directed toward the "academic" quality of the faculty as defined by the degrees held and the need for faculty holding "terminal degrees." For the historic learned professions this was not a problem; the $\mathrm{DD}$. MD, JD, or accepted equivalents were routinely held by members of the corresponding professions. For engineering, management, and the other newer professions, the terminal degree was defined as the Ph.D. or equivalent. Active adjuncts had in too many cases been defined out of the field. In the professional societies also, the role of the practicing engineer or manager began to change. Academic members faced with "publish or perish" requirements became the major contributors to meeting agendas and professional journals. Non-academics took on an increasingly passive role.

This was balanced by another phenomenon. Increased need for and interest in continuing education led to the rapid expansion of evening and extension courses. Most of these tended to be in engineering and management. At the same time faculty course loads were decreasing to make way for increased research and publication. Graduate students took some of the slack but increasingly it was necessary to turn to adjuncts to staff courses. Adjuncts were too often looked on as second class stand-ins or "warm bodies" filling vacant lines in the class schedules. Too often also they perceived themselves in the same way. They were assigned classes, syllabuses, and textbooks and took as given the academic teaching role assigned. During this process, the potential for the practical, "clinical," and critical perspectives for which they are particularly fitted have too often be lost.

\section{Building a New Type of Graduate Faculty}

The authors believe that a major task in reshaping graduate education for engineers and technology leaders in industry lies in building new types of high caliber, professionallyoriented faculty by drawing from the multidisciplinary resources of core faculty that already exist within the engineering schools and university system and from the resource base of experienced adjunct faculty that exists within the practicing profession in regional industry who are at the cutting edge of technological advancements, policy making and engineering leadership.

"Proceedings of the 2002 American Society for Engineering Education Annual Conference \& Exposition Copyright $@$ C 2002, American Society for Engineering Education" 
Building an Engaged Professional Faculty of Core Faculty and Adjunct Faculty from Inter-University Resources and Industry. Whereas traditional research-based graduate programs are centered around the hiring of young academic research faculty, primarily from academia, who have the potential or track record to attract research grant funding, the Collaborative believes that different approaches must be developed that are more cost-effective in building a new type, but formidable, blend of professionally oriented graduate faculty from within the total university system and regional industry community to innovate professionally oriented graduate education into existing university cultures.

As Conrad, Haworth, and Millar have pointed out, one of the distinguishing attributes in developing and sustaining high quality professional graduate programs for working professionals is that of employing part-time adjunct professors who work full-time as professionals in the non-university workplace as well as full-time faculty who have spent part of their professional careers in non-university work settings.

Whereas a primary strength of research-based graduate engineering education resides within the academic research faculty, a primary strength of professionally-oriented graduate education resides within the professional-oriented faculty. But they are two different types of faculty, with two different types of missions and scholarly pursuits. In engineering practice (which unfortunately has taken second-class status) practicing faculty, who are at the cutting edge of engineering and technology leadership, bring wisdom, commitment, experience, and corporate memory to professional engineering education. Whereas adjunct faculty have been too often underutilized as warm bodies to fill teaching vacancies in the undergraduate engineering curriculum or to replace buyout monies for the faculty to pursue research grants, at the professional graduate level they bring a wealth of experience in engineering practice, in engineering innovation, and in technology leadership which is vital to the intent and success of this educational innovation.

As Conrad, Haworth, and Millar have pointed out, faculty who had professional experience in settings outside of academe enhanced students" learning experiences in three ways: "First, these individuals provided students with firsthand knowledge of how theories and practices "work" in the real world, information that enabled students to become more effective at translating theory into practice in their professional work situations. Second, such faculty were more aware of the competencies and skills that students needed to perform successfully on the job, and they often were very effective at teaching these skills because they understood their applicability in non-university workplace settings. Third, students often trusted and more easily related to faculty who "has been there," who had been there," who themselves had experienced how difficulty it is to integrate knowledge learned in a range of classes and textbooks and then use it effectively in messy, real-life situations. According to many students and employers, such faculty were important in helping students successful learn how to "work the interface between the workplace and academe."

A Question of Research-Driven Money: Developing Creative Professional Scholarship and Re-Examining Faculty Rewards. For making this educational innovation a reality, the

"Proceedings of the 2002 American Society for Engineering Education Annual Conference \& Exposition Copyright $\odot$ 2002, American Society for Engineering Education" 
National Collaborative recognizes that one of the impediments to creating high quality professionally-oriented graduate education for the engineering workforce across the nation has been an overriding singular emphasis in mission and pursuit of research grants and overhead monies "as the cash cow" at too many universities (as Burr Dean emirtberus of Renselear so prophetically pointed out over thirty years ago), and the lack of vision and mission to provide incentives and reward structure for faculty that encourage sustainable educational innovation in professional education and in building solid on-going relationships with industry.

\section{The ASEE-Green Report pointed out:}

"In whatever way an engineering college defines its mission, to be successful, it must ensure that its faculty reward system supports its goals. Faculty members often face the difficult task of trying to balance the several activities they need for professional advancement. For example, research and undergraduate teaching with a host of new activities their colleagues, students and the public expect them to accomplish. These can include curricula development, interdisciplinary collaboration, work with industry, development of continuing education programs, community outreach, and mentoring of other faculty members and students. As engineering colleges develop institutional missions, they have an opportunity to recraft their faculty reward system to better synchronized faculty rewards with their new, or re-affirmed, institutional expectations.

Changing the faculty reward system will not be an easy task. Faculty rewards are heavily driven by incentives created across the entire university and are part of a nationwide network. Nevertheless, it is important that rewards reflect the goals of the institution and it is important to begin the conversation now. As each institution establishes its vision and charts new directions, it should ensure that its faculty reward system supports the institutional goals."

Thus, a major task in reshaping graduate education will be to begin this task and to define a parallel system of faculty reward for teaching, creative professional scholarship, and professional service that compliments the traditional research-based system for teaching, research, and service in typical universities cultures. Whereas the work of academic research faculty is being measured by the amount of research grants attracted or proposals written, and papers generated in scientific journals, and by teaching, the work of professional oriented faculty must be measured in other ways becau se their scholarly pursuit and mission in engineering practice and leadership of technology development is quite different from academic scientific research.

Developing new sources of funding for professional faculty is a challenge. As Conrad and Haworth have pointed out, one of the most important attributes in developing and sustaining high quality graduate programs for working professionals is that of developing adequate financial support and reward structures for the faculty. Today, there appears to be little question that high quality professionally-oriented graduate education relevant to the practice of engineering and leadership of technology development for the nation's

"Proceedings of the 2002 American Society for Engineering Education Annual Conference \& Exposition Copyright @ 2002, American Society for Engineering Education" 
engineering workforce fits within the mission of engineering schools. The question, however, is how to fund it.

We cannot, nor should we expect research-oriented faculty, who are hired, promoted and tenured on their ability to attract research monies and to build research programs that support research-oriented graduate students, will be rushing to make educational change for professionally-oriented graduate education. At many universities, research is the primary goal and "teaching has become a bothersome chore.

The changing role for a new type of graduate faculty in educating a new type of graduate student population is specifically designed to support educational transformation for career-long learning, growth, professional development, and leadership for creative engineering practice in industry. Non-traditional graduate faculty are at hand and this is an idea whose time is long over due. The transformation neither threatens the research mission nor detracts from the research efforts of research faculty or their institutions, rather it serves to strengthen the professional education mission of universities. New engagement mechanisms of non-traditional graduate education programs provides closer interaction and engagement with industry through the integrative combination of needsdriven directed research. Full-time employees in industry are an untapped lifelong learner who can meet the needs of graduate professional engineer faculty in almost any graduate program. Developing adjuncts as full members of the graduate education faculty will occur through the development and implementation of unique universityindustry-government collaborative partnerships. By working together in new engagement mechanisms to strengthen real-world engineering innovation and then bringing it into the graduate classroom, requires existing graduate education faculty, department heads/chairs and deans to take a prominent leadership role in being proactive in the promotion of developing adjuncts as full graduate education faculty. Graduate education schools throughout the United States can no longer afford not to recognize and promote practicing engineers to appropriate graduate education faculty status. Doing this when other nations are investing heavily in the education of their engineers and technology leaders is mission critical for all engineering and technology graduate education programs.

\section{References}

1. Stevens, E.W., Jr., The Grammar of the Machine, (105-132), New Haven: Yale University Press, 1995.

2. Calvert, M.A., The Mechanical Engineer in America, 1830-1910, (63-86), Baltimore: The Johns Hopkins Press (1967)

3. Pfammatter, U., The Making of the Modern Architect and Engineer, (265-280), Basel: Birkhäuser (2000)

4. Stevens, E.W., Jr., The Grammar of the Machine, (148-169), New Haven: Yale University Press (1995)

5. Baker, R.P., A Chapter in American Education, (pg. 28), New York: Schribner's (1924)

6. Baker, R.P., A Chapter in American Education, (pg. 32), New York: Schribner's (1924)

7. Baker, R.P., A Chapter in American Education, (pg. 23), New York: Schribner's (1924)

"Proceedings of the 2002 American Society for Engineering Education Annual Conference \& Exposition Copyright $@$ C 2002, American Society for Engineering Education" 
8. Baker, R.P., A Chapter in American Education, (152-161), New York: Schribner's (1924)

9. Pfammatter, U., The Making of the Modern Architect and Engineer, (pg. 276), Basel: Birkhäuser (2000)

10. Calvert, M.A., The Mechanical Engineer in America, 1830-1910, (107-138), Baltimore: The Johns Hopkins Press (1967)

11. Dennison, H., Organizational Engineering, New York: McGraw-Hill (1931)

12. Keating, D.A., Stanford, T.G., Bennett, R.J., Jacoby, \& Mendelson, M.I. Issues in reshaping innovative professionally oriented graduate education to meet the needs of engineering leaders in industry in the $21^{\text {st }}$ century. [CD-ROM]. Proceedings of the $107^{\text {th }}$ Annual American Society for Engineering Education Conference, St. Louis, M.O. (2000).

13. Dunlap, D.D., Depew, D.R., \& Newton, K.A. A different model in graduate education for full-time professionals. [CD-ROM]. Proceedings of the $107^{\text {th }}$ Annual American Society for Engineering Education Conference, St. Louis, M.O. (2000).

14. Keating, D.A., Stanford, T.G., Self, A., \& Monniot, J. Graduate professional education of engineers in industry for innovation and technological leadership. Industry \& Higher Education, 13 (1),33-39 (1999).

15. Hatch, T.F., \& Pearson, T.G. Using environmental scans in educational needs assessment. $J$. Continuing Education in the Health Professions, 18, 179-184 (1998).

16. U of A-IPD. Engineering management program (EMP) needs assessment project report. Edmonton: University of Alberta, Faculty of Extension, Institute for Professional Development. (1999).

17. Babcock, D.L., \& Sachet, D.R. Continuing education for Engineering Management. In, L.P. Grayson \& J.M Biedenbach, (eds.), 1986 World Conference on Continuing Engineering Education (pp. 228 232). May 7-9, 1986, Lake Buena Vista, Florida. New York: IEEE Education Society (1986).

18. Ferguson, $\mathrm{C}$. The continuous professional development of engineers and flexible learning strategies. International Journal of Lifelong Education, 17 (3), 173-183 (1998).

19. National Academy of Engineering. Focus on the future: A national action plan for career-long education for engineers. Washington, D.C.: National Academy of Engineering (ERIC Document ED 300251) (1988).

20. Baker, M. Sharpening the focus of viewpoints between higher education and employers of the expertise required for contemporary and future technical managers. IEEE Transactions on Engineering Management, 40 (3), 211-223 (1993).

21. National Society of Professional Engineers. General characteristics, typical duties and responsibilities of engineers for Levels I - IX. Available WWW: http:www.nspe.org (1999 access date).

22. Estrin, T. Educating the engineering manager: The UCLA experience. In, L.P. Grayson \& J.M Biedenbach, (eds.), 1986 World Conference on Continuing Engineering Education (pp.1088 - 1093). May 7-9, 1986, Lake Buena Vista, Florida. New York: IEEE Education Society (1986).

23. Kocaoglu, D.F. Engineering management: Educational strategies for leadership in technology management. Industry \& Higher Education, 10 (6), 332-336 (1996).

24. Schön, D.A. The reflective practitioner. New York: Basic Books (1983).

25. Kostoff, R.N. Science and technology roadmaps. Springfield, VA: United States Defense Technical Information Center. Available WWW: http:// http://www.dtic.mil/dtic/kostoff/mapweb2index.htm (2001 access date).

26. Keith, K.M. The responsive university in the twenty-first century. In, William G. Tierney (ed.), The Responsive University: Restructuring For High Performance (pp. 162-172). Baltimore: Johns Hopkins University Press (1998).

27. Oblinger, D.G., \& Verville, A. What business wants from higher education. Phoenix, AZ: American Council on Education/Oryx Press (1998).

28. Rhodes, F.H.T. The new university. In, W.Z. Hirsch \& L.E., Weber (eds.), Challenges facing higher education at the millennium (pp. 167-174). Phoeniz, AZ: American Council on Education \& Oryx Press (1998).

29. Kellogg Commission. Renewing the covenant: Learning, discovery and engagement in a new age and a different world. Washington, D.C.: Kellogg Commission on the Future of State and Land-Grant Universities c/o NASULGC. Available WWW: http:// http://www.nasulgc.org/Kellogg/kellogg.htm (2000).

"Proceedings of the 2002 American Society for Engineering Education Annual Conference \& Exposition Copyright @ 2002, American Society for Engineering Education" 
30. Professional Learning Resources, Inc. Current state and best-practice in research university outreach. Unpublished background paper prepared for the Office of the Dean of Extension, University of Alberta. Edmonton, Canada: Professional Learning Resources, Inc (2000).

31. Boyer, E. L. Scholarship revisited: Priorities for the professoriate. Princeton, N.J.: Carnegie Foundation for the Advancement of Teaching (1990).

32. Glassick, C.E., Huber, M.T., \& Maeroff, G.I. Scholarship assessed: Evaluation of the professoriate. San Francisco: Jossey-Bass (1997).

33. Jischke, M.C. The land-grant mission and international outreach. J. Public Service \& Outreach, 3 (3), 3-9 (1998).

34. Mawby, R.G. The challenge for outreach for land-grant universities as they move into the $21^{\text {st }}$ century. J. Public Service \& Outreach, 1_(1), 46-56 (1996).

35. Ray, E. J. Outreach, engagement will keep academia relevant to twenty-first century societies. $J$. Public Service \& Outreach, 4 (1), 21-27 (1999).

36. Votruba, J.C. Strengthening the university's alignment with society: Challenges and strategies. $J$. Public Service \& Outreach, 1 (1), 29-36 (1996).

37. McGrath, C. P. Engagement and the twenty-first century university._J. Public Service \& Outreach, 4 (1), 3-7 (1999).

38. Walshok, M.L. Expanding roles for research universities in regional economic development. New Directions for Higher Education \#97 (The University's Role in Economic Development), 25 (1), 17-26 (1997).

39. Walshok, M.L. Knowledge without boundaries: What America's research universities can do for the economy, the workplace, and the community. San Francisco: Jossey-Bass (1995).

40. Cervero, R.M., \& Wilson, A.L. The politics of responsibility: A theory of program planning for adult education. Adult Education Quarterly, 45, 249-268 (1994).

41. Wenger, E. Communities of practice: Learning, meaning and identity. New York: Cambridge University Press (1998).

42. Garvin, D. A. Learning in action: A guide to putting the learning organization to work. Boston: Harvard Business School Press (2000).

43. Keating, D.A., Stanford, T.G., Dunlap, D.D., Aherne, M.J., Mendelson, M.I., Enhancing U.S. Technology Development Through Lifelong Education of Engineers and Technologists as Creative Professionals, Proceedings of the Proceedings of the $108^{\text {th }}$ Annual American Society for Engineering Education Conference, Albuquerque, NM (2001).

\section{BIOGRAPHICAL INFORMATION}

\section{DUANE D. DUNLAP}

Duane D. Dunlap is a Professor and Department Head of Engineering Technology at Western Carolina University (WCU). Before coming to WCU, Dr. Dunlap was the Founding Director of the Weekend Master's Degree Program for the School of Technology at Purdue University. Duane's degrees in technology and education are from The OSU \& LSU receiving his Doctor of Education from Virginia Tech. Visit http://et.wcu.edu to learn more.

\section{RAYMOND WILLIS}

Raymond E. Willis is Professor Emeritus of Strategic Management at the Curtis L. Carlson School of Management and Adjunct Professor at the University of St. Thomas. Ray is the author of A Guide to Forecasting for Planners and Managers and co-author of Statistic Analysis and Modeling for Decision Making. Additionally, he has taught and lectured at universities in Canada, France, and China as well as the United States.

\section{DONALD A. KEATING}

Donald A. Keating is an Associate Professor of Mechanical Engineering at the University of South Carolina teaching in the areas of mechanical engineering and the engineering leadership of technology. Don received his Master of Science in Mechanical Engineering from the University of Dayton and the Master of Engineering in Mechanical Engineering from Cornell University. 


\section{THOMAS G. STANFORD}

Thomas G. Stanford is an Assistant Professor of Chemical Engineering at the University of South Carolina teaching in the areas of thermodynamics and chemical process design. Tom received his Ph.D. in Chemical Engineering from the University of Michigan.

\section{RONALD J. BENNETT}

Ronald J. Bennett is Director of the Graduate Engineering and Technology Management programs and Chair of undergraduate Engineering at St. Thomas. Ron holds a Ph.D. in Metallurgical Engineering and an MBA. Ron has received the AEC, NSF and Island Steel Company fellowships. Currently, he is Program Chair for the Graduate Studies Division of ASEE and is an ABET program evaluator.

\section{MICHAEL AHERNE}

Michael Aherne is an Associate at the Institute for Professional Development at the University of Alberta. He holds degrees in business and education (adult, career and technology education) from the University of Alberta. Michael has a broad range of consulting, management and operations experience in Canada's education, international energy, health and transportation industries.

\section{MEL I. MENDELSON}

Mel I. Mendelson is an Associate Professor of Mechanical Engineering and director of the engineering and production management graduate program at LMU (Los Angeles, CA). Mel's interests include failure analysis, integrated product development and creative problem solving. He received his B.S. from UC Berkeley, his M.S. and Ph.D. Northwestern University all in materials science. He has 20 years of industrial experience. 